\title{
FORMULASI RANSUM ALTERNATIF UNTUK MENINGKATKAN EFISIENSI USAHA PETERNAKAN SAPI PERAH (STUDI KASUS PADA PETERNAKAN BESTCOW FARM JEMBER)
}

\section{The Alternative Ration Formulation to Improve Efficiency of Dairy Cow Farming Business (Case Study on Bestcow Farm Jember)}

Huda Ahmad Hudori ${ }^{1}$, Hari Rujito ${ }^{1}$, Muksin ${ }^{1}$, Fredy Eka Ardhi Pratama ${ }^{1}$, dan Paramita Andini ${ }^{1}$ ${ }^{1}$ Jurusan Manajemen Agribisnis, Politeknik Negeri Jember

Email: huda.hudori@polije.ac.id

\begin{abstract}
INTISARI
Penelitian ini bertujuan untuk mengkaji formulasi ransum alternatif sapi perah yang paling murah dan menganalisis pendapatan serta efisiensi biaya pada usaha sapi perah Bestcow Farm Jember. Penelitian ini dilakukan di peternakan sapi perah Bestcow Farm Jember. Pemilihan lokasi penelitian menggunakan purposive sampling dengan pertimbangan peternakan Bestcow Farm memiliki populasi ternak sapi perah yang cukup banyak yaitu 50 ekor. Parameter penelitian yang diambil yaitu formulasi ransum alternatif, analisis pendapatan, dan efisiensi biaya. Penelitian ini menggunakan metode deskriptif berdasarkan hasil pengumpulan data yang diperoleh dari wawancara langsung dengan karyawan perusahaan dan recording Bestcow Farm. Formulasi ransum alternatif 2 adalah formulasi ransum alternatif dengan harga paling murah. Formulasi ransum alternatif tersebut layak untuk diaplikasikan pada usaha sapi perah Bestcow Farm Jember untuk mendapatkan pendapatan yang lebih tinggi.
\end{abstract}

Kata Kunci: Efisiensi Usaha, Formulasi Ransum, Peternakan Sapi Perah

\begin{abstract}
This study aimed to examine the formulation of the cheapest alternative dairy rations and analyze the income and cost-efficiency of Bestcow Farm Jember. This research was conducted at Bestcow Farm Jember. The research location was chosen using purposive sampling with the consideration that Bestcow Farm has a fairly large population of dairy cattle, 50 heads. The research parameters taken were alternative ration formulations, income analysis, and cost-efficiency. This research used a descriptive method based on the results of data collection obtained from direct interviews with company employees and Bestcow Farm recording. The alternative ration formulation 2 was an alternative formulation ration with the cheapest price. This alternative ration formulation was feasible to be applied to Bestcow Farm Jember to get higher income.
\end{abstract}

Keywords: Business Efficiency, Alternative Ration, Dairy Farm

\section{PENDAHULUAN}

Usaha peternakan sapi perah adalah usaha dengan prospek pengembangan yang cerah karena dilihat dari laju permintaan susu yang terus mengalami peningkatan, adanya dukungan perbaikan manajemen, teknologi, infrastuktur, dan kebijakan dari pemerintah. Pengembangan usaha peternakan sapi perah merupakan salah satu alternatif dalam rangka pemenuhan gizi masyarakat terutama yang berasal dari protein hewani terutama susu. Prediksi perkembangan industri pengolahan susu di Indonesia bahwa konsumsi susu masyarakat pada tahun 2020 adalah sebesar 6 milyar liter setara susu segar atau 16,5 juta liter per hari (Cahyawati, 2015).

Populasi ternak sapi perah di Indonesia tahun 2015 tercatat 519.000 ekor (Direktorat Jenderal Peternakan dan Kesehatan Hewan, 2018). Sapi perah di Indonesia 97\% dari populasi terkonsentrasi di Pulau Jawa dengan rataan produksi susu per ekor sekitar 11 sampai 12 liter/hari (Cahyawati et al., 2014). Produksi tersebut masih jauh di bawah produksi susu yang seharusnya. Salah satu 
usaha yang dapat dilakukan adalah dengan pengembangan sapi perah untuk menunjang peningkatan produksi susu dalam negeri. Selama ini, pemerintah Indonesia mengatasi kekurangan pasokan susu dalam negeri dengan melakukan impor susu dari Australia dan New Zealand. Saat ini susu segar dalam negeri (SSDN) baru mencapai 30\% kebutuhan nasional, sedangkan 70\% dipenuhi melalui impor (Cahyawati, 2015). Produksi susu nasional di Indonesia dari tahun 2011 sampai 2015 disajikan pada Tabel 1.

Tabel 1. Produksi Susu Nasional Tahun 2011-2015

\begin{tabular}{lrrrrr}
\hline \multirow{2}{*}{ Provinsi } & \multicolumn{5}{c}{ Produksi Susu (Ton) } \\
\cline { 2 - 6 } & \multicolumn{1}{c}{2011} & \multicolumn{1}{c}{2012} & \multicolumn{1}{c}{2014} & \multicolumn{1}{c}{2015} \\
\hline Jawa Barat & 302.603 & 281.438 & 255.548 & 258.999 & 260.823 \\
Jawa Tengah & 104.141 & 105.516 & 97.579 & 98.494 & 99.577 \\
Jawa Timur & 551.977 & 554.312 & 416.419 & 426.254 & 426.557 \\
Provinsi lain & 15.973 & 18.466 & 17.300 & 17.004 & 18.406 \\
\hline \multicolumn{1}{c}{ Total } & 974.694 & 959.732 & 786.846 & 800.751 & 805.363 \\
\hline
\end{tabular}

Direktorat Jenderal Peternakan (2015)

Peningkatan produksi susu sapi perah perlu dilakukan karena peluang pasar di dalam negeri sangat terbuka lebar mengingat sekitar $70 \%$ kebutuhan susu nasional masih diperoleh dari impor dengan volume impor pada tahun 2015 sebesar 286.412 ton. Saat ini populasi sapi perah di Indonesia masih terpusat di pulau Jawa dengan sebaran Provinsi Jawa Timur 45,6\%, Jawa Tengah 27,7\%, Jawa Barat $23,5 \%$, dan 3,2\% sisanya Provinsi lain (Direktorat Jenderal Peternakan, 2015). Indonesia memiliki potensi yang sangat besar di sektor agribisnis. Kekayaan sumberdaya agribisnis berperan sebagai pendukung usaha peternakan sapi perah, sehingga istilah Indonesia sebagai kolam susu akan terwujud serta dapat menjadi lokomotif bagi stimulasi pembangunan nasional.

Perusahaan sapi perah mempunyai tujuan untuk mendapatkan keuntungan yang sebesar-besarnya. Adapun untuk memperoleh keuntungan yang besar suatu usaha sapi perah perlu melakukan efisiensi di dalam menggunakan biaya produksi guna mendapatkan output susu segar yang banyak. Salah satu cara yang dapat dilakukan untuk menekan pengeluaran biaya operasional pada usaha peternakan sapi perah adalah dengan menekan biaya pakan lebih murah sehingga akan diperoleh keuntungan yang optimal.

Pakan sapi perah dapat diperoleh dengan mencari dan mengelola bahan pakan potensial lokal untuk diformulasikan sesuai dengan kebutuhan nutrisi ternak. Umela dan Bulontio (2016) menyatakan bahwa seekor ternak akan berproduksi dengan baik apabila kebutuhan nutrisi yang diantaranya untuk hidup pokok, produksi susu, pertumbuhan, dan reproduksi dapat terpenuhi.

Komponen pakan merupakan biaya produksi paling besar dan terus mengalami kenaikan setiap tahunnya. Bahan pakan yang akan digunakan sebaiknya memiliki kriteria sebagai berikut: palatabilitasnya tinggi, kandungan nutriennya baik, tersedia setiap saat dan tidak bersaing dengan manusia, serta memiliki harga yang terjangkau (Firman, 2010). Kenaikan biaya pakan tidak diikuti dengan kenaikan harga output yang signifikan. Hal ini dikhawatirkan akan berpengaruh terhadap perkembangan usaha peternakan sapi perah. Salah satu upaya yang dapat dilakukan ialah dengan cara menekan biaya pakan melalui penyusunan formulasi pakan menggunakan bahan pakan lokal yang memiliki potensi berlimpah.

Bestcow Farm merupakan salah satu perusahaan sapi perah yang ada di Jember. Perusahaan tersebut memiliki permasalahan usaha peternakan yaitu mahalnya biaya pakan. Oleh karena itu, penelitian ini dilakukan untuk mengetahui bagaimana menyusun formulasi pakan alternatif dalam usaha peternakan sapi perah yang dapat meningkatkan output sehingga tercapai efisiensi usaha pada peternakan sapi perah Bestcow Farm Jember.

\section{METODE PENELITIAN}

\section{Lokasi Penelitian}

Penelitian ini dilakukan di peternakan sapi perah Bestcow Farm Jember. Pemilihan lokasi penelitian ini menggunakan purposive sampling dengan pertimbangan peternakan 
Bestcow Farm memiliki populasi ternak sapi perah yang cukup banyak yaitu 50 ekor.

\section{Rancangan Penelitian}

Penelitian ini menggunakan metode deskriptif berdasarkan hasil pengumpulan data yang diperoleh selama penelitian. Bahan pakan yang ada di Bestcow Farm dibuat formulasi ransum alternatif 1,2 , dan 3 . Formulasi ransum alternatif yang termurah kemudian dibandingkan dengan formulasi di Bestcow Farm.

\section{Pengumpulan Data}

Data penelitian diperoleh dari data primer dan sekunder. Data primer adalah data yang diperoleh dari wawancara langsung dengan karyawan perusahaan. Data sekunder merupakan data yang diperoleh dari hasil pencatatan Bestcow Farm dan Dinas
Peternakan, Perikanan dan Kelautan Jember. Data yang dikumpulkan meliputi biaya-biaya yang dikeluarkan selama kegiatan usaha berlangsung dan penjualan hasil produksi berupa susu segar dan pedet.

Adapun bahan pakan ternak dalam penelitian ini yang akan digunakan untuk menyusun ransum alternatif sapi perah pada peternakan sapi perah Bestcow Farm Jember terdiri dari dua jenis bahan pakan yaitu pakan yang berasal dari hijauan dan konsentrat seperti yang disajikan pada Tabel 2 . Penyusunan ransum ternak sapi perah menggunakan metode trial and error dengan aplikasi microsoft excel pada fasilitas solver (Destarianto et al., 2018). Kebutuhan nutrisi sapi perah dengan bobot badan 400-450 kg, produksi susu 10-15 liter kadar lemak 4\% yaitu $16 \mathrm{~kg} \mathrm{BK}, 14,1 \%$ (2,256 kg) PK, 68\% TDN (10,88 kg), dan 12,3\% SK (NRC, 2001).

Tabel 2. Daftar Bahan Pakan Ternak dan Kandungan Nutrisi

\begin{tabular}{|c|c|c|c|c|c|c|}
\hline \multirow{2}{*}{ No. } & \multirow{2}{*}{ Bahan Pakan } & \multicolumn{4}{|c|}{ Kandungan Nutrisi } & \multirow{2}{*}{$\begin{array}{c}\text { Harga } \\
\text { (Rp/Kg) }\end{array}$} \\
\hline & & BK (\%) & PK (\%) & SK (\%) & TDN (\%) & \\
\hline $\mathrm{A}^{*}$ & Hijauan & & & & & \\
\hline 1 & Kulit kedelai & 89 & 20,3 & 31,7 & 56 & 300 \\
\hline 2 & Jerami jagung & 28 & 8,2 & 29,8 & 57 & 250 \\
\hline 3 & Jerami padi & 86 & 3,7 & 35,9 & 39 & 200 \\
\hline 4 & Jerami kedelai & 36 & 12,1 & 47,85 & 42,74 & 150 \\
\hline 5 & Rumput gajah & 21 & 8,3 & 33,5 & 50 & 300 \\
\hline 6 & Okra & 18,5 & 17,03 & 41,66 & 50,56 & 200 \\
\hline $\mathrm{B}^{* *}$ & Konsentrat & & & & & \\
\hline 1 & Ampas tahu & 22 & 11,5 & 5,8 & 84 & 500 \\
\hline 2 & Ampas singkong & 86 & 1,61 & 15,2 & 80 & 150 \\
\hline 3 & Dedak padi & 83 & 12,2 & 8,9 & 65,7 & 1800 \\
\hline 4 & Dedak jagung & 81 & 7,54 & 1,5 & 63,4 & 2500 \\
\hline 5 & Bungkil kedelai & 89 & 44 & 6 & 75 & 4000 \\
\hline 6 & Bungkil kelapa & 90,1 & 21 & 10 & 48 & 3000 \\
\hline 7 & Tepung ikan & 91 & 57 & 1,1 & 72 & 6000 \\
\hline 8 & Pollard & 85 & 17 & 8,8 & 74 & 2400 \\
\hline
\end{tabular}

BK = Bahan Kering; PK = Protein Kasar; SK = Serat Kasar; TDN = Total Digestible Nutrient

*Utomo (2012) dan **Agus (2012)

\section{Parameter Penelitian}

\section{Formulasi ransum alternatif termurah}

Penyusunan ransum alternatif mengacu pada kandungan nutrisi bahan pakan seperti pada Tabel 2. Formulasi ransum alternatif yang menghasilkan harga ransum paling murah dibandingkan dengan formulasi ransum yang ada di Bestcow Farm. Formulasi ransum Bestcow Farm yaitu Rp35.850,00.

\section{Analisis pendapatan dan efisiensi biaya}

Analisis pendapatan usaha dihitung menurut Soekartawi (2002) dengan rumus:

$$
\pi=\mathrm{TR}-\mathrm{TC}
$$

Keterangan:

$\pi \quad=$ Pendapatan

$\mathrm{TR}=$ Total penerimaan

$\mathrm{TC}=$ Total biaya 
Total penerimaan usaha Bestcow Farm diperoleh dari hasil penjualan susu segar, pedet, dan induk yang sudah afkir. Total biaya adalah gabungan dari biaya penyusutan dan biaya operasional.

Analisis efisiensi biaya dihitung dengan rumus R/C ratio menurut Soekartawi (2002). Rumus R/C ratio yaitu:

Keterangan:

$$
\begin{gathered}
\mathrm{a}=\mathrm{R} / \mathrm{C} \\
\mathrm{TR}=\mathrm{Py} . \mathrm{Y} \\
\mathrm{TC}=\mathrm{FC}+\mathrm{VC} \\
\mathrm{a}=\mathrm{TR} / \mathrm{TC}
\end{gathered}
$$

a = Efisiensi Biaya

$\mathrm{TR}=$ Total penerimaan $(\mathrm{Rp})$

$\mathrm{TC}=$ Total biaya (Rp)

$\mathrm{FC}=$ Biaya tetap (Rp)

$\mathrm{VC}=$ Biaya variabel (Rp)

Py = Harga susu segar dan pedet (Rp)

$\mathrm{Y}=$ Jumlah susu segar (L) dan pedet (ekor)

\section{HASIL DAN PEMBAHASAN}

\section{Formulasi Ransum Alternatif}

Pakan utama sapi perah berupa hijauan dan konsentrat. Hijauan adalah makanan berserat kasar tinggi, biasanya berupa tanaman jenis rumput dan leguminosa. Konsentrat biasanya berasal dari biji-bijian yang dicampur berdasarkan kandungan nutriennya (Hartadi et al., 2005). Pakan salah satu terpenting dalam usaha peternakan, namun pengeluaran biaya terbesar jika dibandingkan dengan komponen biaya produksi lainnya. Wida (2008) dalam hasil penelitiannya mengatakan bahwa biaya pakan sebesar $60 \%$ dari total biaya produksi. Formulasi pakan dilakukan untuk mendapatkan pakan yang memiliki kandungan

\begin{tabular}{|c|c|c|c|c|c|c|}
\hline \multirow{2}{*}{ Bahan Pakan } & \multirow{2}{*}{ Segar (Kg) } & \multicolumn{3}{|c|}{ Nutrien (Kg) } & \multicolumn{2}{|c|}{ Harga (Rp) } \\
\hline & & BK & $\mathrm{PK}$ & TDN & Segar/Kg & Total \\
\hline \multicolumn{7}{|l|}{ Formulasi 1} \\
\hline Jerami jagung & 15,9 & 4,46 & 0,37 & 2,54 & 250 & 3.980 \\
\hline Jerami kedelai & 13,3 & 4,00 & 0,48 & 1,71 & 150 & 2.000 \\
\hline Ampas tahu & 18,0 & 3,96 & 0,46 & 3,33 & 500 & 9.000 \\
\hline Bungkil kelapa & 3,2 & 2,80 & 0,59 & 1,53 & 3.000 & 9.541 \\
\hline Dedak padi & 3,5 & 2,91 & 0,35 & 2,30 & 1.800 & 6.300 \\
\hline Jumlah & 53,9 & 18,1 & 2,2 & 11,4 & & 30.821 \\
\hline \multicolumn{7}{|l|}{ Formulasi 2} \\
\hline Kulit kedelai & 22,9 & 4,58 & 0,93 & 2,56 & 300 & 6.864 \\
\hline Jerami padi & 12,0 & 3,60 & 0,13 & 1,40 & 150 & 1.800 \\
\hline Pollard & 4,7 & 3,95 & 0,63 & 2,93 & 2.600 & 12.093 \\
\hline Dedak padi & 4,3 & 3,55 & 0,43 & 2,33 & 1.800 & 7.692 \\
\hline Tepung ikan & 0,4 & 0,35 & 0,20 & 0,27 & 5.500 & 2.095 \\
\hline Jumlah & 44,2 & 16,0 & 2,3 & 9,5 & & 30.544 \\
\hline \multicolumn{7}{|l|}{ Formulasi 3} \\
\hline Rumput gajah & 10,7 & 2,24 & 0,19 & 1,12 & 250 & 2.667 \\
\hline Okra & 18,5 & 4,80 & 0,72 & 3,41 & 200 & 3.692 \\
\hline Dedak jagung & 3,6 & 2,88 & 0,22 & 1,83 & 1.500 & 5.333 \\
\hline Bungkil kedelai & 2,8 & 2,48 & 1,09 & 1,86 & 6.000 & 16.719 \\
\hline Ampas singkong & 22,5 & 3,60 & 0,30 & 1,80 & 150 & 3.375 \\
\hline Jumlah & 58,0 & 16,0 & 2,5 & 10,0 & & 31.786 \\
\hline Kebutuhan & & 16 & 2,272 & 10,88 & & \\
\hline
\end{tabular}
nutrien yang sesuai dengan kebutuhan ternak dengan biaya yang murah.

Tabel 3. Formulasi Ransum Alternatif Sapi Perah

Formulasi ransum alternatif 1 terdiri dari 5 bahan pakan yaitu jerami jagung, jerami kedelai, ampas tahu, bungkil kelapa, dan dedak padi. Kandungan nutrisi ransum tersebut yaitu 18,1 kg BK, 2,2 kg PK, 11,4 kg TDN. Hal ini sesuai dengan kandungan nutrien ransum dari 
Bestcow Farm. Proporsi penggunaan masingmasing bahan pakan dapat dilihat pada Tabel 3. Ransum sapi perah tersebut dibuat sebanyak 53,9 kg asfed dengan harga Rp30.821,00.

Formulasi ransum alternatif 2 terdiri dari 5 bahan pakan yaitu kulit kedelai, jerami padi, pollard, dedak padi, dan tepung ikan (Tabel 3). Kandungan nutrien ransum tersebut yaitu $16 \mathrm{~kg}$ BK, 2,3 kg PK, 9,5 kg TDN. Hal ini sesuai dengan kandungan nutrien ransum dari Bestcow Farm. Ransum sapi perah tersebut dibuat sebanyak $44,2 \mathrm{~kg}$ asfed dengan harga Rp30.544,00.

Formulasi ransum alternatif 3 terdiri dari 5 bahan pakan yaitu rumput gajah, okra, dedak jagung, bungkil kedelai, dan ampas singkong (Tabel 3). Kandungan nutrien ransum tersebut yaitu $16 \mathrm{~kg} \mathrm{BK}, 2,5 \mathrm{~kg}$ PK, 10,0 $\mathrm{kg}$ TDN. Hal ini sesuai dengan kandungan nutrien ransum dari Bestcow Farm. Ransum sapi perah tersebut dibuat sebanyak $58 \mathrm{~kg}$ asfed dengan harga Rp31.786,00.

Hasil formulasi ransum tersebut dapat diketahui formulasi 1 memberikan harga yang lebih murah daripada formulasi standar Bestcow Farm sebesar Rp5.029,00. Formulasi 2 memiliki harga yang lebih murah daripada standar Bestcow Farm sebesar Rp5.306,00.
Formulasi 3 memiliki harga yang lebih murah daripada standar Bestcow Farm sebesar Rp4.064,00. Oleh karena itu, dapat diketahui bahwa formulasi 2 memiliki harga paling murah dengan kualitas yang sesuai dengan formulasi ransum Bestcow Farm.

\section{Analisis Pendapatan dan Efisiensi Biaya}

Penerimaan yang diperoleh Bestcow Farm dari tiga sumber output yaitu penjualan susu segar, pedet, dan penjualan induk yang afkir. Penerimaan diperoleh dari penjualan susu segar sebanyak 143.009 L yang dijual ke koperasi susu dengan harga Rp5.250/L. Penerimaan dari penjualan susu segar yaitu sebesar Rp750.797.250,00 (71,88\% dari total penerimaan), penjualan pedet sebesar Rp136.500.000,00 (16,15\%), dan penjualan induk afkir sebesar Rp125.000.000,00 (11,97\%). Total penerimaan Bestcow Farm sebanyak Rp1.012.297.250,00 (Tabel 4) pada tahun penelitian.

Biaya pakan dalam usaha peternakan sapi perah terus mengalami kenaikan yang tidak dapat diprediksi sehingga menyebabkan kerugian. Hal ini mengindikasikan bahwa titik kritis keberhasilan pada suatu usaha peternakan sapi perah terletak pada upaya menurunkan biaya penggunaan bahan pakan.

Tabel 4. Analisis Pendapatan dan Efisiensi Biaya Ransum di Bestcow Farm

\begin{tabular}{|c|c|c|c|c|c|}
\hline \multirow{2}{*}{ No. } & \multirow{2}{*}{ Jenis Biaya } & \multicolumn{2}{|c|}{ Ransum Bestcow Farm } & \multicolumn{2}{|c|}{ Ransum Alternatif 2} \\
\hline & & $(\mathrm{Rp})$ & $(\%)$ & (Rp) & $(\%)$ \\
\hline \multirow[t]{5}{*}{ A } & Total penerimaan & & & & \\
\hline & - Susu segar & 750.797 .250 & 71,88 & 750.797 .250 & 71,88 \\
\hline & - Pedet & 136.500 .000 & 16,15 & 136.500 .000 & 16,15 \\
\hline & - Induk afkir & 125.000 .000 & 11,97 & 125.000 .000 & 11,97 \\
\hline & Total & 1.012.297.250 & 100 & 1.012 .297 .250 & 100 \\
\hline \multirow[t]{6}{*}{ B } & Total biaya & & & & \\
\hline & - Biaya penyusutan & 170.402 .857 & 17,82 & 170.402 .857 & 19,05 \\
\hline & - Pakan & 645.300 .000 & 67,48 & 572.155 .359 & 64,05 \\
\hline & - Tenaga kerja & 36.000 .000 & 7,53 & 36.000 .000 & 8,06 \\
\hline & - Lain-lain & 104.760 .000 & 7,17 & 104.760 .000 & 8,81 \\
\hline & Total & 956.462 .857 & 100 & 883.318 .216 & 100 \\
\hline $\mathrm{C}$ & Pendapatan (A-B) & 55.834 .393 & & 128.979 .034 & \\
\hline $\mathrm{D}$ & Efisiensi biaya (A/B) & 1,06 & & 1,15 & \\
\hline
\end{tabular}

Penggunaan ransum alternatif mampu menurunkan biaya pakan lebih murah dibandingkan biaya pakan sebelumnya karena formulasi ransum alternatif sapi perah yang disusun menggunakan bahan-bahan dari limbah hasil pertanian dan industri. Utomo (2012) yang menyatakan bahwa pakan ternak dapat berasal dari hijauan pakan, hasil samping tanaman pertanian, hasil pertanian, hasil samping industri pertanian, hasil 
samping industri perkebunan, dan hasil industri kelautan. Persentase biaya usaha sapi perah dengan menggunakan ransum alternatif 2 (termurah) dapat dilihat pada Tabel 4 .

Total biaya usaha peternakan sapi perah Bestcow Farm selama tahun penelitian sebesar Rp956.462.857,00 yang terdiri dari biaya penyusutan Rp170.402.857,00, biaya pakan Rp645.300.000,00, biaya tenaga kerja Rp36.000.000,00, dan biaya lain-lain sebesar Rp104.760.000,00 yang terdiri dari biaya inseminasi buatan (IB), vitamin dan obat, tenaga kerja, listrik, air, dan biaya bahan bakar.

Komponen biaya pakan sebesar $67,48 \%$ dari total biaya (Tabel 4). Hal ini sesuai pendapat Wida (2008) bahwa biaya pakan pada usaha peternakan mencapai 60 sampai $70 \%$ dari total biaya produksi. Selain pakan, menurut Budiarsana (2016) faktor yang menentukan tingkat keuntungan usaha peternakan sapi perah adalah produktivitas dan biaya-biaya yang digunakan untuk pemeliharaan

Pendapatan yang diterima oleh Bestcow Farm yaitu sebesar Rp55.834.393,00/tahun, sedangkan pendapatan dengan menggunakan ransum alternatif 2 diperoleh pendapatan sebesar Rp128.979.034,00/tahun. Pendapatan usaha dari Bestcow Farm menjadi lebih tinggi jika menggunakan ransum alternatif 2 dengan selisih Rp73.144.641,00. Nilai efisiensi biaya yang diperoleh Bestcow Farm sebesar 1,06 lebih kecil daripada menggunakan ransum alternatif 2 nilai efisiensi biaya sebesar 1,15.

Hasil perhitungan tersebut dapat diartikan bahwa usaha peternakan sapi perah Bestcow Farm apabila menggunakan ransum alternatif 2 dari setiap pengeluaran sebesar Rp1 akan diperoleh pendapatan sebesar Rp1,15. Artinya ransum alternatif 2 layak untuk diaplikasikan. Menurut Asnidar dan Asrida (2017) bahwa R/C ratio lebih dari 1 berarti usaha yang dijalankan tersebut mengalami keuntungan atau layak untuk dikembangkan. Semakin besar nilai R/C ratio berarti semakin besar penerimaan yang diperoleh dibandingkan dengan biaya produksi yang dikeluarkan (Mamondol, 2016).

\section{KESIMPULAN}

Formulasi ransum alternatif 2 adalah formulasi ransum alternatif dengan harga paling murah. Formulasi ransum alternatif tersebut layak untuk diaplikasikan pada usaha sapi perah Bestcow Farm Jember untuk mendapatkan pendapatan yang lebih tinggi.

\section{DAFTAR PUSTAKA}

Agus, A. 2012. Bahan Pakan Konsentrat Untuk Sapi. PT. Citra Aji Parama. Yogyakarta.

Asnidar dan Asrida. 2017. Analisis kelayakan usaha home industry kerupuk opak di Desa Paloh Meunasah Dayah Kecamatan Muara Satu Kabupaten Aceh Utara. Jurnal Sains Pertanian. 1(1): 39-47.

Budiarsana, I.G.M. 2016. Penggunaan fungsi "solver" dalam formulasi pakan termurah untuk peternak sapi perah skala kecil. Informatika Pertanian. 25(2): 231-240.

Cahyawati, A.E., B.P. Purwanto, dan Suryahadi. 2014. Analisis efisiensi teknis pada usaha peternakan sapi perah rakyat di Kecamatan Lembang. Jurnal Sains Terapan. 4(2): 46-56.

Cahyawati, A.E. 2015. Analisis Efisiensi Teknis, Keterampilan Teknis Beternak dan Pendapatan pada Usaha Peternakan Sapi Perah Rakyat di Kecamatan Lembang. Tesis. Sekolah Pascasarjana Institut Pertanian Bogor. Bogor.

Destrianto, P., A. Sutirtoadi, dan N. Faizah. 2018. Desain aplikasi penentuan formulasi ransum pada ternak sapi potong. Jurnal Teknologi Informasi dan Terapan. 5(1): 43-48.

Direktorat Jenderal Peternakan dan Kesehatan. 2018. Statistik Peternakan dan Kesehatan Hewan 2018. Direktorat Jenderal Peternakan dan Kesehatan Hewan Kementerian Pertanian RI. Jakarta

Direktorat Jenderal Peternakan. 2015. Buku Statistik Peternakan dan Kesehatan Hewan. Kementerian Pertanian. Jakarta.

Firman, A. 2010. Agribisnis Sapi Perah dari Hulu sampai Hilir. Widya Padjadjaran. Bandung.

Hartadi, H., S. Reksohadiprodjo, and A.D. Tillman. 2005. Indonesian Feed Composition Tables. Gadjah Mada University Press. Yogyakarta.

Mamondol, M.R. 2016. Analisis kelayakan ekonomi usahatani padi sawah di Kecamatan Pamona Puselemba. Jurnal Envira. 2(1): 1-10. 
NRC. 2001. Nutrient Requirement of Dairy Cattle. 8th Edition. National Academic of Science. Washington D.C.

Soekartawi. 2002. Prinsip Dasar Ekonomi Pertanian, Teori dan Aplikasinya. PT. Raja Grafindo Persada. Jakarta.

Umela, S. dan N. Bulontio. 2016. Daya dukung jerami jagung sebagai pakan ternak sapi potong. Jurnal Technopreneur. 4(1): 6472.

Utomo, R. 2012. Bahan Pakan Berserat untuk Sapi. Cetakan Pertama. PT. Citra Aji Parama. Yogyakarta.

Wida, E. 2008. Formulasi Kombinasi Optimum Faktor-faktor Produksi Usaha Peternakan Sapi Perah Rakyat di Kabupaten Boyolali. Sains Peternakan: Jurnal Penelitian Ilmu Peternakan. 6(2): 31-44. 